\title{
Challenges and Opportunities for Regional Integration in Africa: The Case of Sadc
}

\author{
Tanyanyiwa, Vincent Itai ${ }^{1} \&$ Hakuna, Constance ${ }^{2}$ \\ ${ }^{I}$ Department of Geography and Environmental Studies. Zimbabwe Open University. P.O.Box MP 1119. Mt. \\ Pleasant. Harare. Zimbabwe \\ ${ }^{2} 68$ Richwell Avenue. Mabelreign. Harare. Zimbabwe
}

\begin{abstract}
Regional integration is useful for economic, political and social development of countries. Despite the numerous efforts by African states to form regional trading blocs, existing Regional Economic Communities (RECs) in Africa have not been successful achieving their intended objectives of poverty reduction and economic development. This paper looked into regional integration in Africa, with particular focus on the Southern African Development Community (SADC). The research was a qualitative case study. SADC is largely unable to sustain its operations in case of donor funding cessation. Intra-SADC trade is low, though large by African standards. Factors that influence intra-SADC trade were highlighted as lack of industrial capacity within SADC, high cost of doing business, slow implementation of agreements, and lack of private sector participation, geographical proximity and presence of institutional frameworks. There is need for SADC to explore regional value chains as a way of boosting intra-regional trade.
\end{abstract}

Keywords: Free Trade Area, Regional Integration, Regional Economic Communities, SADCC, SADC

\section{Introduction}

The importance of regional economic cooperation and integration as a means for accelerating and consolidating economic and social development has long been recognised by African decision-makers (Lebale et al, 2009). The Post-Independence era saw African governments embracing the idea of regional integration, initially mainly for political reasons and later as a development strategy to rise above challenges of small markets, landlockedness and to benefit from economies of scale in production and trade. Today's globalised world, as well as Africa's risk of further marginalization in a multi-polar world dominated by trading blocs in North America, Europe, South-East Asia and China, have presented African regional economic integration as an imperative (Madyo, 2008). Lebale et al (2009) also states that regional integration could lead to, inter alia, pooling of resources and enlarged local markets for stimulating production, trade and investment. Second, with the current financial and economic crisis affecting African economies through decreases in Official Development Assistance (ODA), imports and investments, the intensification of intra-African trade offers one development strategy for trade diversification.

African States have entered into a number of regional integration agreements; and currently there is no country in Africa that is not a member of at least one regional economic group (Alemayehu and Haile, 2002). Examples of regional integration arrangements currently in place in Africa include the East African Community (EAC) in East Africa, the Economic Community of West African States (ECOWAS) in West Africa, the Economic Community of Central African States (ECCAS) in Central Africa, the Southern African Development Community (SADC) and the Common Market for Eastern and Southern Africa (COMESA) in Southern and Eastern Africa.

In addition to agreements at a regional level, attempts have also been underway to create economic cooperation (and ultimately meaningful economic integration) among African countries at a continental level (Alemayehu and Haile, 2004). According to Hatzernberg (2011), the aspiration of African leaders to integrate Africa, provided the rationale for the Lagos Plan of Action (LPA). The LPA was an initiative of the Organization of African Unity (OAU), adopted by Heads of State in April 1980. The plan aimed at increasing Africa's self-sufficiency and reducing dependency on the Western countries. The Abuja Treaty was signed in 1991and was the impetus for the African integration agenda. This treaty emphasized African solidarity, selfreliance and an endogenous development strategy through industrialisation. The treaty came into force in 1994 and envisaged the development of an African Economic Community by 2028.Leaders at the African Union (AU) Summit which took place in January 2012 under the theme 'Boosting intra-African trade' endorsed a plan to set up a Continental Free Trade Area (CFTA) by 2017. The proposed CFTA would be a key component of the AU's strategy to boost trade within the region by at least 25-30 percent in the next decade (International Centre for Trade and Sustainable Development, 2012). There are serious efforts aimed at achieving regional integration in Africa, mainly with a view to alleviate poverty, generate employment, and improve per capita 
incomes and overall standard of living of African countries through boosting trade amongst African countries themselves. Despite such efforts, however, existing Regional Economic Communities (RECs) in Africa have not been successful in fully achieving their intended objectives.

\subsection{Statement Of The Problem}

Regional integration is a tool that can be used for the economic, political and social development of countries. Countries all over the world are engaging in regional integration arrangements due to their immense benefits in stimulating development. Regional Economic Communities (RECs) in developed countries have achieved significant successes in regional integration as evidenced by increases in intra-regional trade and resultant increases in economic growth and development e.g. the European Union (EU) and the Association of South East Asian Nations (ASEAN). In Africa, ECOWAS, EAC, COMESA and SADC have played a crucial role in enhancing the political, social and economic development of their Member States, although to a lesser extent than the European and Asian RECs. The continental hope for poverty reduction and economic development rests largely upon regional integration as evidenced by the African Union's goal of establishing an African Economic Community by 2028, yet current regional integration arrangements have not yet fully succeeded in achieving this goal. There is thus need for an analysis to be done on the challenges and opportunities of regional integration within Africa in order for African RECs to obtain the best from regional integration. According to Chingono and Nakana (2008) the African Union has identified economic cooperation and integration as the engine to propel African development and regional economic communities such as SADC, as pillars for continental integration and development. Against this assertion, it is crucial to analyse the challenges and prospects presented by SADC integration in order for appropriate action to be taken to obtain the best out of regional integration, not only in Southern Africa, but in Africa as a whole. The focus SADC was premised on our being Zimbabweans, SADC being one of the longest-standing RECs to which Zimbabwe is a member and Zimbabwe's biggest trading partner is South Africa, which is also in SADC. This study analysed opportunities and challenges of regional integration in SADC.

1.2 Objectives: The study sought to answer the following questions:

- What are the opportunities and challenges for integration in SADC?

- What are the factors that influence intra-SADC trade?

- Is SADC sustainable?

\subsection{Conceptualizing Regional Integration}

\section{Literature Review}

Regional integration can be likened to a team, where people from diverse backgrounds, with unique ways of thinking and differing personalities come together to work towards achieving a common goal. As the famous Shona saying goes "Chara chimwe hachitswanyi inda," literally translated to mean "one finger cannot destroy a louse", it means there is much benefit to be derived when people come together in pursuit of a common purpose. The concept of regional integration can be viewed in the same way; hence regional integration can be generally defined as the coming together of nations to attain a common goal. Just as it is in a team, regional integration comes with its pros and cons which shall be illustrated later in this discussion. There is neither a clear definition of integration nor consensus on its substantive content and form, let alone agreement on paradigms that should inform (Chingono and Nakana 2008). The lack of clarity and consensus on the guiding paradigm for regional integration and how to achieve it is perhaps one of the key explanatory factors for limited progress in some Regional Integration Arrangements (RIAs).

Regional integration, or more crudely 'regionalism' is any policy designed to reduce trade barriers between a subset of countries regardless of whether those countries are actually contiguous or even close to each other (Winter, 1996; Mengesha, 2009). One of the most striking features of international economic integration is that the great majority of Regional Integration Arrangements (RIAs) involve neighboring countries (hence the term "regional"). The main exceptions are the Asia-Pacific Economic Cooperation (APEC), the Group of Three (Mexico does not border either Colombia or Venezuela), various plurilateral Free Trade Areas (the EU with South Africa, with Mexico, and with Chile), and bilateral FTAs such as those between Canada and Chile, Chile and Mexico, and Israel and the United States (Schiff and Winters, 2003). Mambara (2007) defines regional integration as the formation of closer economic linkages among countries that are geographically near each other especially by forming preferential trade agreements (PTAs). For the purpose of this research, the researcher shall define regional integration as the latter has put it across.

\subsection{Rationale for Regional Integration}

Regional integration (RI) has become very popular all over the world as a way in which countries can overcome small markets, pool resources and benefit from economies of scale in production and trade. Regional integration increases competition in global trade and improves access to foreign technology, investment, and 
ideas (UNECA 2010). African leaders thus consider it an important path to broad-based development and a continental economic community, in accordance with the Treaty Establishing the African Economic Community (1991) and the Constitutive Act of the African Union (2000). Tomlinson (2008) argues that regional integration and cooperation also offers possibilities to ensure much improved and more sustainable management of shared natural resources-water and sensitive ecosystems, in particular, and to more effectively address regional commons, such as migratory diseases and climate change.

RI has always been viewed as the most promising approach to overcome the economic balkanisation of many parts of the African continent. Colonial borders in Africa have divided once connected economic spaces and networks and eventually created a patchwork of small economic entities that are unable to overcome the narrowness and limitations of their markets by themselves. Today 38 out of the 54 African states have populations of less than 15 million people and one third of all African countries have less than 3 million inhabitants. The integration of these small states provides a larger population and thus demand base allowing industries to benefit from economies of scale and thus efficiencies in production coupled with enlarged markets. Development experts argue that African countries need to formulate, publicise and defend their often similar interests regarding global developments. This could be achieved more easily if African countries would no longer speak as individual countries but as regional blocs (Peters-Berries, 2010).

Countries also enter into RIAs in order to enhance their political, environmental and social agendas; however the scope of this study, as mentioned earlier will target mainly issues to do with the economic implications of regional integration. Peters-Berries (2010) also articulates that regional integration can attract additional development funding as donors are sometimes more willing to fund regional projects as opposed to development projects in individual countries. This is particularly relevant for regional integration in developing countries or regions and has been put forward as a pragmatic view and as a result of practical experiences (Peters 1987; Peters-Berries, 2010).

\subsection{Economic Benefits of Regional Integration}

Alemayehu and Haile (2007) highlight that the impetus for regional integration draws its rationale from the standard trade theory which states that free trade is superior to all other trade. When countries come together to form trading blocs, the idea is that these countries will benefit from free trade by doing away with all forms of barriers to trade amongst themselves. However, Alemayahu and Haile proceed to state that, free trade will only improve the welfare of member countries as long as the regional integration arrangement leads to a net trade creation. Tau (2000) posits that, although theories of economic integration show that integration may have both positive and negative outcomes, dominant views indicate that regional integration may improve the welfare of member states.

Keane et al (2010) observed that there is a fierce debate across the globe about the merits of regional trading agreements. Keane et al (2010) further highlight that, while some herald such agreements as stepping stones towards worldwide free trade, others fear that these initiatives will be stumbling blocks, acting primarily to divert trade from other countries to those countries receiving preferential treatment. Although these issues are essential for the future of the world's trading relationships, a number of obstacles prevent a consensus to be reached on the effects of preferential trading agreements. All formal regional integration arrangements reduce barriers (such as tariffs) to trade among member countries. Economic theory predicts that free trade will improve welfare by enabling citizens to procure goods and services from the cheapest source, leading to the reallocation of resources based on comparative advantage. It is thus tempting to conclude that regional integration arrangements will generate welfare gains (UNECA, 2010).

The literature on regional integration dates back to (Viner, 1950; Schiff and Winters, 2003), who suggested that the effects of regional integration on trade can be either, trade creating or trade diverting. Like any form of liberalization, one intended effect of an RIA is to allow the more efficient producers in the region to expand production (and reap economies of scale) to the advantage of consumers and the detriment of less competitive producers. This is called trade creation. Trade diversion occurs when the removal of tariffs within the region leads to goods that were previously imported from outside (from the cheapest global source) being replaced by more expensive goods produced inside the region which can be sold for less because they no longer have to pay any import duty. Consumers still gain, although by less, but governments lose more in tariff revenue and the country as a whole is able to obtain fewer imports for a given value of exports. This implies that regional integration can lead to further trade, but that these flows may not always be welfare enhancing (Schiff and Winters, 2003).

Schiff and Winters (2003), further posit that the welfare effect of an RIA on the bloc members as a group depends on the balance between trade creation and diversion. Real resources are saved if inefficient production is cut through trade creation but are lost if imports are switched from low-cost to high-cost partner sources through trade diversion. Effects from entry into a regional integration scheme can be divided into static and dynamic effects. Keane et al (2010) highlight that static effects are a result of resource allocation in 
response to changing relative prices, and dynamic effects, come from changes in efficiency, ability to exploit economies of scale, and in level of investment and growth. Keane et al (2010) further explain the dynamic effects to include, the competition effect, brought about by freeing imports from partner countries, the investment effect, which appears when there are new foreign and domestic investments that have not occurred in the absence of regional trade integration, the larger market providing greater possibilities for the exploitation of economies of scale, capital formation, possibly through various channels: reduction on barriers to diffusion, technological transfer, externalities from export growth and rising marginal product of capital, the union members acting as a group increasing their chance to influence the terms of trade they face and the structural transformation effect, which is a shift from traditional primary-products export to new industrial-products export.

UNECA (2004) posits that the similarities and differences of African countries could make regional integration and cooperation beneficial. Many African countries share common resources, such as rivers and problems, such as HIV/AIDS and low agricultural productivity, but they also exhibit important differences, particularly in their endowments. Though most have limited resources, some have well-trained workers, some have rich oil deposits, some have water resources suitable for hydroelectric generation, and some have excellent academic institutions and capacity for improving research and development. By pooling their resources and exploiting their comparative advantages, integrated countries can devise common solutions and use resources more efficiently to achieve better outcomes.

\section{Theoretical Framework}

Theories of RI are many, and include functionalism, relativism, dependency and neo-classical theory. However this study chose the dependency theory because of the original ideas of SADC formation highlighted above.

\subsection{Dependency Theory}

According to Inotai (1991), regional integration is considered a useful tool for loosening and gradually eliminating the historically economic and structural dependence of developing countries on the developed world. Dependency theorists argue that poverty in the periphery (poor countries) is not because they are not integrated into the world system, or not 'fully' integrated as is often argued by free market economists, but because of how they are integrated into the system. Castaneda further implores that poor nations provide natural resources, cheap labour, a destination for obsolete technology, and markets to the wealthy nations, without which the latter could not have the standard of living they enjoy. First World nations actively, perpetuate a state of dependency through various policies and initiatives. This state of dependency is multifaceted, involving economics, media control, politics and all aspects of development. Any attempt by the dependent nations to resist the influences of dependency will result in economic sanctions or military invasion and control.

Proponents of the dependency theory, suggest that the panacea for dependency lies in reducing links to the core (developed countries) through import-substitution industrialization and South-South co-operation, which is co-operation between or among developing nations or simply put, regional integration. However, the dependency theory has been criticized for lacking practical strategies on how developing countries can de-link themselves from the developed countries and for ignoring the endogenous factors within countries and RECs that limit development in developing countries (Friedmann and Wayne, 1977). In the practical sense, RIAs in developing countries have not reduced dependence on the developed world. Inotai (1991) states that dependence on the core (rich nations) has actually increased, even after implementation of RIAs, as financial flows, technological and managerial skills as well as trade links could not be substituted by intra-regional assets.

SADC is no exception in terms of dependence on donors for SADC programs and operations. Sources of funding in SADC are derived from the annual Member States contributions as well as funding support received from International Co-operating Partners (ICPs) including amongst others, the African Development Bank, European Union and the African Union. Annual Member States contribution distribution formulae are calculated on the basis of GDP of the respective Member States (SADC, 2012). McLeod (2003) highlights that ownership of programmes by receivers of donor funds must be strong. If a donor forces its own ideas onto a partner, the programme is unlikely to succeed and it undermines the sustainability of the programme. There is need to establish whether SADC is sustainable in the event that donors or international cooperating partners were to pull out, as the researchers are not wary of any research that has looked at this aspect. Part of the objectives of this study is to thus determine SADC's sustainability with regards to this facet.

\section{Regional Integration In Europe}

Theories of integration have mainly been developed to explain European integration. Europe was the region of the world, where regional integration started in the early 1950s with the European Coal and Steel Community (ECSC) in 1952 (Laursen, 2008). The European Union is probably the most successful, most influential and most often copied model for RI. It started from very modest beginnings of a functional cooperation between six countries in Western Europe in the area of mining. The architects of the post-war RI in 
Western Europe had political motives: the prevention of a future war between 'arch enemies' France and Germany and the formation of a counterweight to the perceived threat from Soviet-controlled Eastern Europe. They combined these cleverly with a particular economic interest, the supply of sufficient raw materials for the production of energy and steel in order to provide the desperately needed ingredients for economic revival in the participating countries to start the European integration process (Peters-Berries, 2010).

Peters-Berries (2010) further illustrates that the European integration process has led to a number of remarkable achievements, which are:

- Free trading within the EU through the establishment of a customs union. The EU boasts of the highest intra-regional trade among its member states, with intra-EU trade at 66\%;

- Free movement of people in 15 core countries; citizens can decide where they want to live, work, invest and/or travel to without restrictions and border controls; as of 2014 there are 28 member states in EU.

- European citizenship, which is expressed by the introduction of European passport (Schengen );

- The introduction of a single currency, the Euro $(€)$, in the majority of the member states in 2002;

- The harmonisation of laws and regulations regarding economic, environmental, health, social and transport issues;

- The transfers of parts of national sovereignty to supranational EU institutions.

Laursen (2008) attributes successes of the EU to the feedback mechanism that was instituted to obtain feedback from the general populace concerning European integration. Non-state actors would lobby for certain policies or frameworks they would want from the integration process and member states in some cases could actually vote in favour of or against certain policies within the EU. According to Cameron (2010), support from the United States was also crucial in the early years of European integration as well as the political will to share sovereignty and construct strong, legally based, common institutions to oversee the integration project and a consensus approach combined with solidarity and tolerance. The EU approach is based on not isolating any member state if they have a major problem (such as Greece in the most recent crisis), hesitance to move forward with policies until the vast majority of member states are ready, and a willingness to provide significant financial transfers to help poorer member states catch up

Cameron (2010) however notes that, while the European Union (EU) has long been the most developed model of regional integration, it was severely shaken by the recent economic crisis, causing increasing doubts about the integration process. The lack of a timely and coherent response to the Euro Crisis called into question the integrity of the Euro Zone, whose structural and institutional fault lines have been revealed by the financial crisis. Peters-Berries (2010) echoes the same sentiments pointing out that despite all the successes, the regional integration process has slowed down in the last years because of an increasing hesitance in some member states to relinquish more of their national sovereignty to the EU. Peters-Berries (2010) goes on to highlight that, regardless of the evident problems, the EU is still by far the most advanced RI project in the world. Although EU member states are generally rich, lessons from European integration have universal relevance thus:

- Economic interests alone are not a sufficient base for RI; it requires an expressed political will to be successful.

- The interests of smaller and/or weaker states must be respected and safeguarded in the process of RI so that the project is not dominated by the economically and politically most powerful countries.

- Successful RI requires institutionalized mechanisms to ensure a 'just' distribution of costs and benefits from the integration process.

- A common political history and similar political cultures and values help to develop a common regional identity.

- Adherence to similar democratic and legal standards is crucial for the functioning and acceptance of the integration process in member states.

\section{Regional Integration In Asia}

Trade in Asia more than doubled between 1995 and 2010 (Ko, 2013). According to Peters-Berries (2010), the major RI project in Asia is the Association of Southeast Asian Nations (ASEAN), with its headquarters in Jakarta / Indonesia, and established in 1967 in Bangkok by Indonesia, Malaysia, the Philippines, Thailand and Singapore. Peters-Berries (2010) highlights that right from the start, ASEAN had a clear anticommunist outlook pursued an approach of strengthening national sovereignty and of consolidating the independence of its member states. In contrast to the European Union, the foundation of ASEAN was not to ultimately prepare for gradually surrendering national rights to a regional institution but to serve nationalist interests. As a result of the strong emphasis placed on national sovereignty the principle of non-interference into internal affairs of the member states was introduced. According to Ko (2013), the Asian success story holds a lesson for Africa. 
By fostering regional integration, Asia was able to create regional value chains and thus become more efficient. ASEAN thus became a key player in global value chains, which today increasingly characterise world trade (close to $30 \%$ of world trade). ASEAN, however, remains a strictly inter-governmental body with no indication of interest in sovereignty sharing. No other regional body is anywhere near the EU in terms of political or economic cooperation, let alone integration. Indeed, no other grouping has even gotten to first base in terms of the basic requirements of integration, namely dealing with historical reconciliation and developing the necessary political will. In East Asia, for example, there can be no integration without genuine reconciliation between Japan and China, and Japan and Korea. Only after historical reconciliation, (such as that of France and Germany in the case of the EU) can countries proceed gradually along the various steps required to create a regional community such as a customs union, a single market, a single currency, a common passport area, and a common foreign policy (Cameron, 2010).

The ASEAN Free Trade Area (AFTA) established in 1992 was agreed upon in order to improve the region's international competitiveness by eliminating tariffs and non-tariff barriers internally (Peters-Berries, 2010). The Common Effective Preferential Tariff (CEPT) accord / scheme, a phased programme of tariff reductions, was initially scheduled to pave the way for AFTA and to become effective in 2008. This was, however, brought forward and AFTA was already achieved by 2003. Hence the FTA became effective even before the stipulated timeframe. This could come as a lesson to Africa that in order to advance deeper regional integration it would be prudent to prioritize the establishment of the necessary frameworks before the timeframes for establishing FTAs, CUs or monetary unions (MUs). The ASEAN has been successful in achieving a substantial increase in intra-ASEAN trade which currently stands at around 25\% (Ko, 2013). In the past 50 years, East Asia has grown rapidly through the expansion of trade. Flows of capital and skilled workers across countries continue to provide an important avenue for technology transfer. The East Asian countries have successfully assimilated technology by sending students abroad, exploiting linkages with overseas nationals, and encouraging exchanges with research centres (Clapham et al, 2001).

\section{Regional Integration In Africa}

Since independence, African countries have pursued regional integration arrangements to accelerate their economic, social and political development. The first generation regional integration schemes were motivated partly by the political vision of African Unity, but also as a means for providing sufficient scale to import substitution industrialization policies (Kritzinger, undated). Nevertheless, history has shown that the ISI policies not only failed in individual countries but also in the regional integration groupings. Such arrangements launched to fallout of fashion in the 1970s, in part because the first experiences were not successful (William et al, 1997; Mengesha 2009). However, in the late 1980s and early 1990s, regional integration has again become an attractive policy option, in both the developed and developing world. In this regard, since the end of cold war and with the emergence of powerful trading blocs, there has been a renewed interest in Africa concerning the need to create strong regional economic integration (REI) mechanisms to promote economic growth (Baldwin, 1997; Mengesha, 2009).

As increasingly recognized by Africa's leaders and partners, the cost of the continent's geographic, political and economic fragmentation and its separation from international markets is rising, in many ways becoming untenable. Some countries enjoy the windfall gains of historically high oil prices, while many others struggle with power-shortages and rolling blackouts. Most suffer from insufficient scale in production and lack of international competitiveness due to high costs and low reliability of transport, power, and telecoms combined with often prohibitive intra-African barriers on the flow of goods, capital and people (World Bank, 2008). Mengesha (2009) also draws attention to the fact that Africa is confronted with deep rooted level of poverty, minimal share of world trade, and low pace of development in infrastructure and faces excess challenges from external pressures. Ensuring that regional economic integration succeeds in Africa is vital hoping that it will help in enhancing economic development and growth in the continent.

From the continental level there is a strong belief that regional integration will accelerate the development of Africa. According to Hatzenberg (2011), the aspiration of African leaders to integrate Africa, provided the rationale for the Lagos Plan of Action (LPA). The LPA was an initiative of the Organization of African Unity (OAU), adopted by Heads of State in April 1980, and aimed at increasing Africa's selfsufficiency and reducing dependency on the Western countries through the coming together of African states. A decade later in 1991 the Abuja Treaty was signed, providing strong support for the African integration agenda. This Treaty emphasized African solidarity, self-reliance and an endogenous development strategy through industrialization. This treaty came into force in 1994 and envisages the development of an African Economic Community by 2028. According to the OECD (2010), the desire to integrate African economies on a regional, and ultimately continental, basis is strong. It is shared amongst African elites and their international development partners. Consequently many formal initiatives have been established to further this goal, under the over-arching umbrella of the African Union's plan to achieve a continental common market by 2028. 
Leaders at the African Union Summit which took place in January 2012 under the theme 'Boosting intra-African Trade' endorsed a plan to set up a Continental Free Trade Area (CFTA) by 2017. The proposed CFTA would be a key component of the AU's strategy to boost trade within the continent by at least $25-30 \%$ in the next decade (International Centre for Trade and Sustainable Development, 2012). African leaders now recognize more than ever the urgency of accelerating Africa's integration, especially given the challenges of regionalism amid globalization. This urgency is reflected in the above-mentioned initiatives and in the establishment of the Commission of the African Union and the orientation of the units of the Commission. To move the regional integration process forward, African countries have also adopted the New Partnership for Africa's Development (NEPAD), the overarching development framework for the region, recognized by the United Nations and its agencies and such global bodies as the G-8 industrial countries (UNECA, 2004).

UNECA (2004) further notes that the World Trade Organization's rules for the world trade system have heightened global competition and raised the stakes for Africa. Crawford and Fioretino (2005) in Kalaba and Tsedu (2008) echoes that slow progress under the recent multilateral WTO trade negotiations (under the Doha Development Round) seems to have, in turn, further triggered the creation and settlement of these regional economic integration schemes At sub-regional levels, countries have also committed themselves to various RIAs, and currently there is no country in Africa that is not a member of at least one regional economic group (Alemayehu and Haile, 2008). Examples of regional integration arrangements currently in place in Africa are the East African Community (EAC) in East Africa, the Economic Community of West African States (ECOWAS) in West Africa, the Economic Community of Central African States (ECCAS) in Central Africa and the Southern African Development Community (SADC) and the Common Market for Eastern and Southern Africa (COMESA) in Southern and Eastern Africa. COMESA, EAC and SADC are currently negotiating for the establishment of an expanded free trade agreement, the COMESA-EAC-SADC FTA also referred to as the Tripartite FTA (TFTA). Amongst the goals of the TFTA is to increase intra-regional trade and investment thereby maximizing economic growth and development (Ndomo, 2009). Ndomo (2009) further states that the African Union recognizes eight RECs out of the 14 RECs in Africa to be the building blocs for the proposed African Economic Community and these are the Arab Maghreb Union (UMA), East African Community (EAC), Economic Community of West African States (ECOWAS), Community of Sahel-Saharan States (CENSAD), Economic Community of Central African States (ECCAS), Common Market for Eastern and Southern Africa (COMESA), Inter-Governmental Authority on Development (IGAD) and Southern African Development Community (SADC).

According to the African Union Chairperson (Dr. Dhlamini-Zuma) at the $33^{\text {rd }}$ SADC Summit of Heads of State and Government which was held in August, 2013 in Malawi, ECOWAS has made great strides in the movement of business persons and COMESA and EAC have registered significant increases in intra-regional trade over the past few years. Although RIAs hold immense potential for individual countries and the continent as a whole, their success at achieving their intended goals of increasing economic development and alleviating poverty within Member States has been minimal. Trade in Asia more than doubled between 1995 and 2010 whereas trade in sub-Saharan Africa has largely stalled at a mere $2 \%$ of world total. African exports remain highly focused on commodities - they account for over half of sub-Saharan exports compared to just about $10 \%$ for Asia and advanced economies. Despite numerous commitments to create integration zones, Africa continues to register the lowest percentage of trade worldwide - a mere $12 \%$ cent of total exports take place within Africa, compared with 25\% in ASEAN and over 60\% in the European Union(Ko, 2013).

\section{Southern African Development Community (Sadc)}

SADC is a Regional Economic Community comprising 15 Member States in Southern Africa namely; Angola, Botswana, Mozambique, Zimbabwe, South Africa, Zambia, Lesotho, Mauritius, Namibia, Democratic Republic of Congo, Madagascar, Malawi, Seychelles, Swaziland and Tanzania. The Southern African Development Coordinating Conference (SADCC) the precursor to SADCC was established in1980, with the specific aim of reducing economic dependence on apartheid South Africa, which was still excluded from the African integration plan (Hatzernberg, 2011). Initially SADCC had an agenda that was political. However SADCC became the Southern African Development Community (SADC) in 1992 with a more economic agenda of integrating markets and an aim to improve the livelihoods of its people through increased regional trade (SADC, 2008). The combined income of the SADC market is US $\$ 432$ billion and comprises a total population of about 248 million. South Africa is the biggest economy with a GDP of US\$282 billion representing 65\% of the total SADC market (SADC, 2008). Hatzenberg (2011) highlights that SADCC was established in 1980, by the following Front Line states; Angola, Botswana, Lesotho, Malawi, Mozambique, Swaziland, Tanzania, Zambia and Zimbabwe with the specific aim of reducing economic dependence on apartheid South Africa 
Fig 1: Map of SADC

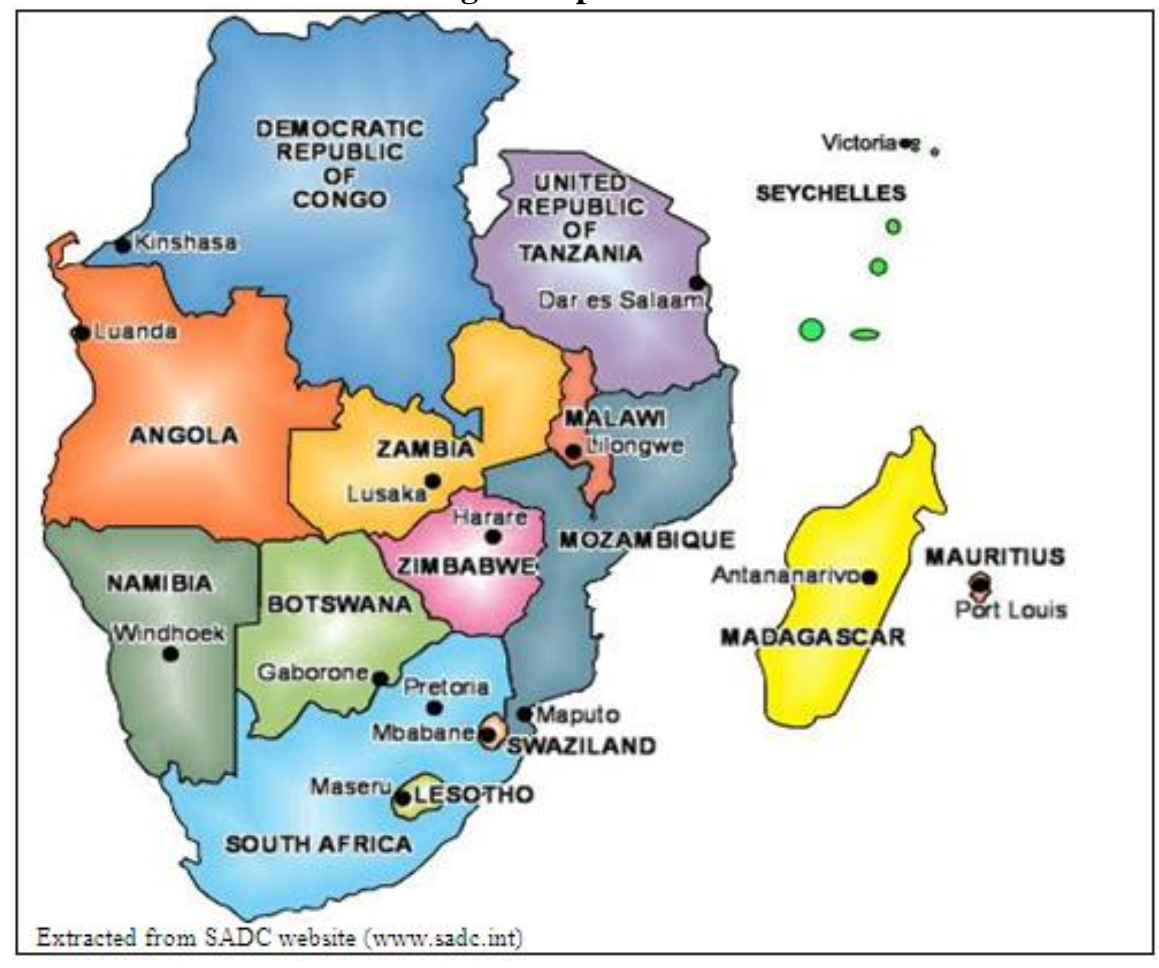

SADCC's original strategy was to concentrate on promoting co-operation in infrastructure. Its primary activities were the co-ordination of members' development initiatives and assistance in raising funds for these projects. SADCC however, had limited success in economic co-operation and development. However, it has been claimed that the old SADCC always portrayed itself as an economic body although it was more political and ideological (Mengesha, 2009). In 1992, SADCC became the Southern African Development Community (SADC) which was more economically inclined. SADC is committed to regional integration and poverty eradication within Southern Africa through economic development and ensuring peace and security (SADC, 2012). The 1992 SADC Treaty changed a loose organization of member states into a legally binding arrangement to facilitate closer economic integration between members and formed part of the continent's drive to harmonize RECs further to the establishment of the African Economic Community (AEC) in the 1991 Abuja Treaty.

SADC has faced a number of challenges in achieving its objectives of economic growth and poverty reduction. SADC member states are poor. This is shown in the low levels of intra-SADC trade which is currently at about $15 \%$ (www.sadc.int). Kalenga (2012) highlights that SADC has failed to achieve its goals of deepening regional integration SADC region has the potential to bring more arable land under cultivation and to start using modern irrigation systems that could reduce dependence on rain-fed agriculture. At present, less than $20 \%$ of arable land in SADC is under cultivation, and only $10 \%$ of available water is used for irrigation. The hydro-electric potential in SADC is estimated at well over 142,000 megawatts per year, and the region is exploiting only $7 \%$ of this potential.

\section{Materials And Methods}

The research design applied in this study is a qualitative case. Yin (1984) in Schell (1992) defines a case study is an empirical enquiry which investigates a contemporary phenomenon within its real life context, when the boundaries between phenomenon and context are not clearly evident and in which multiple sources of evidence are used. The main objective of this study was to analyze the potential and challenges of regional integration in SADC. Data was collected data through desk study review method and in-depth interviews. Key informants purposively sampled were from relevant Government Ministries which deal with SADC and trade issues, as well as other trade-related institutions. The desk study review collected secondary data and the indepth interviews collected primary data. 


\subsection{Union}

\section{Results And Discussion}

This study revealed that the issue of multiple memberships, whereby member states belong to more than one regional grouping is one of the challenges hindering a CU in SADC. Multiple memberships of member states in SADC to other regional integration arrangements was found to have negative connotations towards the feasibility of a customs union within SADC.

\subsection{Unwillingness of member states to give up their sovereignty}

Customs Unions, as entailed in the review of literature entail that member states have to cede their sovereignty as some economic and political decisions have to be made by the customs union. This study found out that countries within SADC are generally unwilling to give up or share their sovereignty as happened in European integration. Part of the reason why the EU succeeded in implementing a CU is because member states were willing to share their sovereignty, something which SADC countries have shown to be not too eager to do. A survey carried out by another interviewee further confirmed that member states in SADC are not willing to share sovereignty. This further presents challenges for a customs union within SADC.

\subsection{Delays in consolidation of SADC Free Trade Area (FTA)}

The literature reviewed shows that, in order to proceed to a customs union, SADC should have completed tariff reductions in an FTA agreement and all member states should be participating in the FTA. Currently, although SADC is an FTA, not all countries have completed their commitments under the FTA. There are three countries not participating in the FTA and some countries have not fully implemented tariff phasedowns for the FTA.

\subsection{Over- Dependence on Donor Funds}

SADC has two main sources of finance; member states' contributions and funding from International Cooperating Partners (ICPs). This study found that SADC is highly dependent on donor funds. Results from interviews revealed that more than $50 \%$ of the funding within SADC is from ICPs with the EU being the major donor of SADC. Although member states make annual contributions towards SADC, these are insufficient to meet the costs of the REC with capacity gaps covered by donors, although not adequately. There is also a risk of donors advancing their own agendas in SADC through conditionalities attached to aid. As stipulated by the dependency theory, breaking free from dependence on donors is difficult as donors may instill punishments for attempts to break away. Donors may thus, manipulate certain positions within SADC in order to advance their own agendas because of the influence they hold as major funders.

However, one of the findings of the research is that, due to the reduced funding from ICPs, member states have slowly realised the disadvantages of over-reliance on donor funding and SADC has recently developed a Resource Mobilisation strategy which suggests mechanisms which can mobilize resources for the REC to reduce dependency on RECs. Included in this strategy are plans to establish a Regional Development Fund and Public-Private Partnerships which are meant to bridge the finance gap in SADC.

\subsection{Intra-SADC trade against other RECs}

The literature reviewed in this study established that intra-regional trade in Africa is generally low as compared with other RECs in other parts of the world as illustrated by Fig 3 below

Fig 2: Intra-Regional Trade of selected RECs in Africa

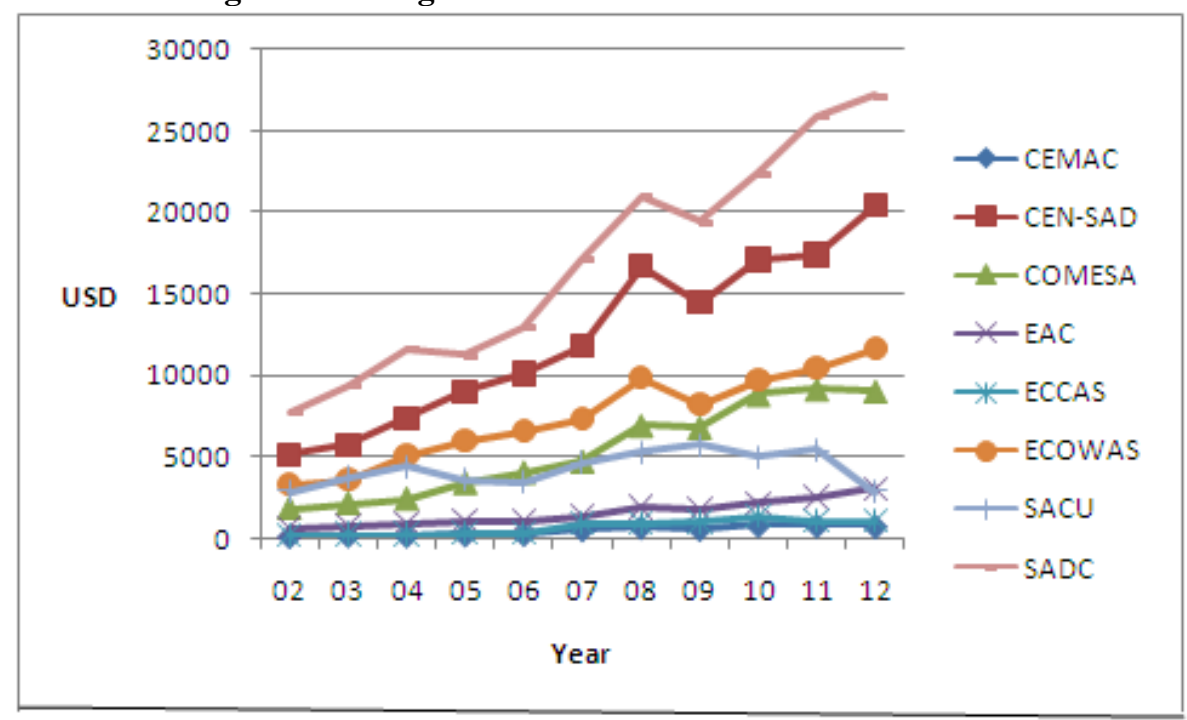

Graph deduced from UNCTAD Statistics (2013) 
Fig 2 indicates that in comparison with other RECs in Africa, SADC actually has a higher intraregional trade which has been experiencing an upward trajectory since 2002-2012. Scholars have attributed high levels of intra-SADC trade to the high trade of other member states with South Africa. Conversely, it can be noted from the graph that SACU's intra-regional trade is quite low as compared to SADC and other RECs and has been fairly constant over the period 2002 to 2012, yet it also has South Africa as a member state.

EAC has the highest intra-regional trade in the African region. Hence, the findings in Fig 2 contrary to what some scholars have suggested and according to the findings of this study using UNCTAD data, there is evidence to suggest that intra-SADC trade is higher than intra-EAC trade. Moreover, it is the highest in Africa among the 8 RECs it has been compared with, which are the major RECs out of the 14 African RECs. However, although it may be the highest in the African region, when compared to other international RECs it can be seen that trade within SADC is significantly low. This is shown in Fig 3 below.

Fig 3: Intra-regional Trade: SADC and International RECs

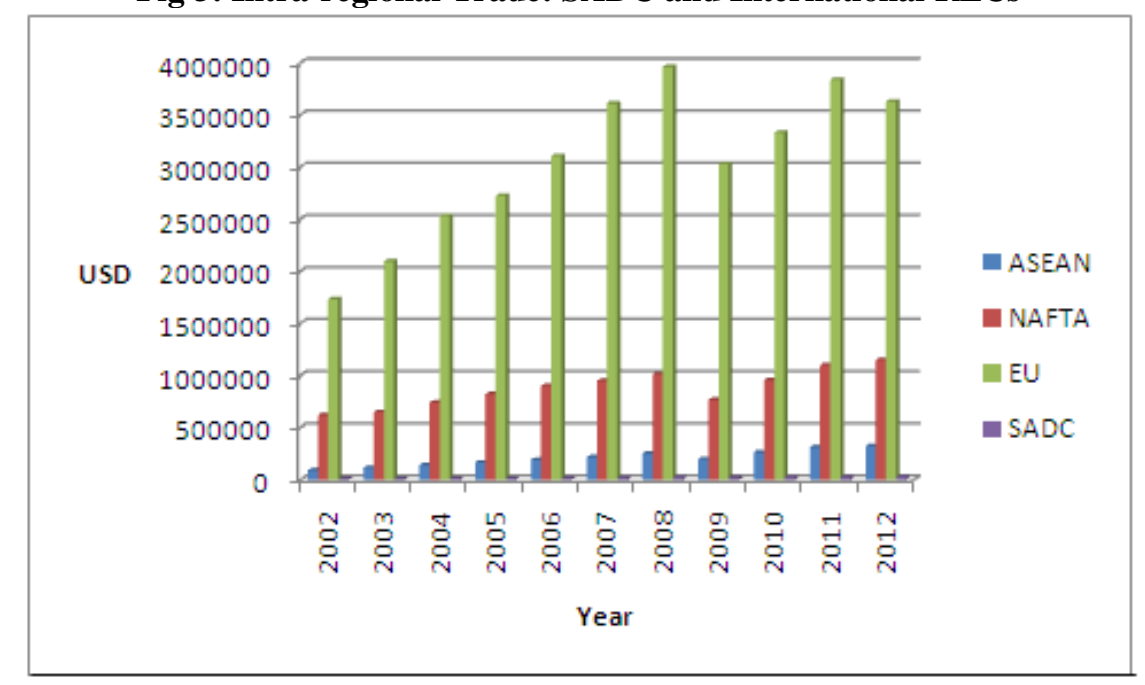

Graph deduced from UNCTAD Statistics (2013)

As shown Fig 4, intra-SADC trade is almost insignificant compared with intra-regional trade in the European, American and Asian RECs of the EU, NAFTA and the ASEAN. The EU has the highest level of intra-regional trade, followed by NAFTA, the ASEAN and lastly SADC. There is thus evidence to suggest that indeed intra-SADC trade is low, as other scholars have posited

\subsection{Lack of industrial capacity in SADC}

\section{Factors Influencing Intra-Sadc Trade}

The non-diversity of exports within SADC is considered a major factor affecting intra-SADC trade. Most scholars argue that countries tend to trade more with countries with diversified exports and the findings of this study have found this trend to hold within SADC. SADC countries lack industrial capacity for diversified manufactured goods. As a result, the exports within SADC countries often comprise of goods which are of little value to other African states.

\subsection{High cost of doing business within SADC}

The high cost of business is a result of infrastructural gaps e.g. at border posts, transport and Information and Communication Technology (ICT) networks. This leads to duplicative border procedures, cumbersome paper requirements and the lack of free movement of people and goods across borders. The restrictive Rules of Origin within SADC were also found to increase the cost of doing business in SADC

10.3 Slow implementation of agreements

Intra-SADC trade is influenced by the slow implementation of RIAs designed to eliminate tariff and non-tariff barriers to trade within SADC. The SADC Free Trade Area was launched in 2008, but up to now (2014), not all countries within SADC are participating in the FTA, and some have not reduced their tariffs in tandem with the required tariff phasedowns in the FTA.

\subsection{Lack of private sector participation}

The private sector and other non-state actors in SADC member states play an insignificant role in SADC negotiations. Most member states when negotiating at SADC fora are usually represented by top government officials. The private sector, if represented, is often by Chambers of Commerce, which usually offers misguided advice. Intra-regional trade in the EU and Asia is higher than in SADC. 


\subsection{Geographical Proximity}

The research found that geographical proximity is considered a positive factor that influences intraSADC trade. In some instances there is evidence from the study to show that countries sometimes considered geographical proximity within their SADC RIA to consider which countries to trade with. Furthermore, integration in SADC creates relationships which encourage trade among member states. This is contrary to what other scholars posit that geographical proximity has no role to play in regional integration. However this study found geographical proximity to be a factor which positively influences intra-SADC trade.

\subsection{Presence of Institutional Frameworks}

This study found that SADC has a number of institutional frameworks that are being put in place and some which have already been put in place to promote intra-SADC trade, which are not found in other RECs across Africa. Such frameworks, which have been mentioned earlier, include propositions for operationalization of a SADC Regional Development Fund, the Regional Industrialization Development Plan and the Resource Mobilization Strategy. These frameworks, if they become operational can positively influence intra-SADC trade. The SADC Protocol on Trade as well as the follow-ups by the SADC Secretariat on countries that are not yet fully participating in the SADC FTA are all measures which may positively influence intra-SADC trade.

\section{SADCS Strengths}

SADC countries have common cultural and political affinitive which enabled them to solve internal conflicts in individual countries. The signing of the SADC Treaty gave leverage in its negotiations with cooperating governments and international donor institutions, a legal status that its predecessor did not have. The population of SADC is 277 million people; this provides a large market and potential human resource base.

\section{SADCS Constraints}

SADC is a 34 year old institution whose institutions are still weak and the organisation has not come far in the implementation of protocols and regional decisions. What SADC wants to do and actual developments and implementation on the ground are a discord (Tjønneland 2005:181). The SADC Secretariat, the organisation's central executive institution does not have supra-national power, It is primarily an 'administrative body with no formal political power' (2005: 170). SADC over relies on donors thereby compromising on legitimacy in other words is SADC is not transparent and accessible to society in the region (2005: 182). Despite the ambitious goals of the SADC sectoral initiatives, progress made to date has been somewhat limited and it has been widely acknowledged that there is a lack of mechanisms for evaluating and monitoring projects or assessing their effectiveness. Moreover, there is a concern that the organization is still more of a political bloc than a true instrument for regional economic integration. SADC has a disjointed and fractured structure which gives too much power to Heads of State. This means implementation of key policies often does not happen. The Secretariat, as SADC's implementing arm lacks capacity and the authority to enforce decisions and is not empowered to engage in independent diplomatic action to address conflict situations. Conflict resolution processes rely on Heads of State and government and ministerial committees, both of which are invariably committed elsewhere in their political and domestic roles. Due to lack of a permanent mediation unit, the Secretariat has not played a distinct supportive role in preventive and effective diplomacy. This in essence, means that SADC is weak, powerless and impotent in enforcing its decisions. The economic disparities and inequities among Member States, particularly with respect to South Africa is worrying such that there is very minimal trade between and among member states save with South Africa hence the low growth of trade between member states and the subsequent heavy external debt. In the region there is relative or sometimes absolute neglect of rural African populations leading to low levels of income and thus poverty. There is conflicting obligations of some Member States stemming from their membership of the PTA and the Southern African Customs Union. There was lack of institutional reforms for effective transformation from SADCC into SADC; lack of synergy between the objectives of the Treaty on the one hand and the existing SADC [Programme of Action] and institutional framework on the other, and finally lack of appropriate mechanisms capable of translating the high degree of political commitment into concrete programmes of community building and integration (SADC 2003: 4)

\section{Conclusion}

This study has shown that, although there are a number of challenges within SADC integration, there are opportunities ingrained within that can be able to lift Sub- Saharan countries from the myriad of development challenges bedeviling the region. This paper established that due to globalization, Africa is becoming more and more marginalised. Hence it is crucial for African States to integrate and trade amongst each other in order to mitigate the effects of globalization as well as to create larger blocs which can increase their bargaining power at multilateral levels. The study focused mainly on SADC, although reference was also 
made to other success stories in regional integration such as the EU and the ASEAN and how SADC could learn from their experiences.

\section{Recommendations For Sadc}

1. There is need for member states to adopt industrial policies aimed at value addition to their products and to develop industrial chains across the region based on comparative advantage in order for countries to be able to overcome supply-side constraints and to diversify their exports, which will encourage trade amongst themselves.

2. SADC member states are presented with an opportunity in diversifying their products through creativity and innovativeness in order to gain a competitive edge within the large market created by the SADC trading bloc. SADC could also focus on more innovative ways of advancing the integration agenda.

3. SADC could follow the issue of pursuing regional value chains or component manufacture of products, where a raw material for a certain good may be produced in one country, processed in another country and marketed in another leading to an end result which can be labelled a SADC product.

4. SADC member states need to actively engage the private sector in SADC issues and negotiations, since these sectors are crucial in boosting intra-SADC trade. Each member state should encourage participation of non-state actors, through inviting them to meetings and encouraging them to participate and have a more pro-active role to play in SADC issues.

5. For SADC to progress further governments should be prepared to give up their national sovereignty for economic integration to succeed. This entails involvement of the people so that there is free movement of people, capital and labour without need for visas or even passports. Lessons from other regional blocs such EU, EAC and ECOWAS may be invaluable for SADC.

\section{References}

[1]. African Union Chairperson (Dr. Dhlamini-Zuma), (August, 2013), Speech on the opening of the $33^{\text {rd }}$ SADC Summit of Heads of State and Government, Lilongwe, Malawi

[2]. Alemayehu and Haile, (2007), Regional Economic Integration in Africa: A Review of Problems and Prospects with a Case Study of COMESA, University of London \& University of Oxford

[3]. Cameron (2010), The European Union as a model for Regional Integration, Foreign Relations Press, Berlin on http://www.cfr.org/world/european-union-model-regional-integration/p22935 accessed on 14/08/2013

[4]. Cassim.R. (2001), The Determinants of Intra-Regional Trade in Southern Africa with Specific Reference to South Africa and the Rest of the Region, Development Policy Research Unit, University of Cape Town

[5]. Chingono and Nakana (2008), The Challenges of Regional Integration in Southern Africa, African Journal of Political Science and International Relations Vol. 3 (10), pp. 396-408,

[6]. Clapham. C. et al (2001), Regional Integration in Southern Africa: Comparative International Perspectives, South African Institute of International Affairs, Natal Witness Print, South Africa

[7]. Friedmann. H. and Wayne. J. (1977), Dependency Theory: A Critique, Published in The Canadian Journal of Sociology, Vol. 2 (4), pp 399-416, available on www.jstor.org/stable/3340297

[8]. Hatzernberg. T. (2011), Regional Integration in Africa, Trade Law Centre for Southern Africa (TRALAC), South Africa

[9]. Hox and Boejie, (2005) Data Collection: Primary vs. Secondary, Utrecht University, Netherlands

[10]. Inotai. A. (1991), Regional integration Among Developing Countries Revisited, Trade Policy Division, Country economics Department, World Bank, Washington D. C.

[11]. International Centre for Trade and Sustainable Development (ICTSD), (2012), African Union Aims for Continental Free trade Area by 2017 , available on www.ictsd.org/i/news/bridgesweekly/24188

[12]. Kalenga (2012), Regional Integration in SADC: Retreating or forging ahead? Trade Law Centre (TRALAC), South Africa

[13]. Keane et al, (2010), Impediments to Intra-Regional Trade in Sub-Saharan Africa, Overseas Development Institute, London Kritzinger, (undated) Regional Integration: Concepts, Advantages, Disadvantages and Lessons of Experience available on http://siteresources.worldbank.org/EXTAFRREGINICOO/Resources/Kritzinger.pdf

[14]. Ko. C. (2013), Africa: Regional Integration Is a Must for Africa, World Economic Forum, Geneva on http://allafrica.com/stories/201305101741.html accessed on 14/08/2013

[15]. Laursen. F. (2008), Theory and Practice of Regional Integration, Jean Monnet/Robert Schuman Paper Series, Vol (8) No. 3, EU Commission, European Union Centre of Excellence, Miami-Florida

[16]. Lebale. N. et al (2009), Economic Development in Africa Report: Strengthening Regional Economic Integration for Africa's Development, UNCTAD, Geneva

[17]. Madyo. M. R. (2008), The Importance of Regional Integration in Africa, University of South Africa

[18]. Mambara, (2007), Assessment of benefits of regional integration in SADC and COMESA-a gender analysis, Trade and Development Studies Centre [TRADES CENTRE] Harare, Zimbabwe

[19]. McLeod. H. (2003), Regional Integration and the Role of Donors, published in monitoring regional integration in Southern Africa: yearbook. - Stellenbosch: TRALAC, ZDB-ID 20862763. - Vol. 3.2003, p. 220-242, available on http://faculty.ksu.edu.sa/mahmoud/DocLib7

[20]. Mengesha.Y. N. (2009), Trade Effects of Regional Economic Integration in Africa: The Case of SADC, Debre Birhan University, Ethiopia

[21]. Ndomo (2009), Regional Economic Communities in Africa: A Progress Review, Nairobi, Kenya0

[22]. Peters-Berries. C. (2010), Regional Integration in Southern Africa - A Guidebook, Capacity Building International, Germany

[23]. SADC (2008), SADC Free Trade Area Handbook, SADC Publication, Gaborone, Botswana 
[24]. SADC (2012) Resource Mobilisation Strategy, Areas Dynamics, Gaborone Botswana

[25]. Schell. C. (1992), The Value of the Case Study as a Research Strategy, Manchester Business School

[26]. Schiff and Winters (2003), Regional Integration and Development, World Bank, Washington D.C

[27]. Tau. L. M. (2000), Regional Economic Integration in Southern African Development Community: Problems and Prospects, DSpace /Manakin Repository, available on http://hdl.handle.net

[28]. Tjønneland, E.N. (2005) Making SADC Work? Revisiting Institutional Reform. In Monitoring Regional Integration in Southern Africa Yearbook (Vol. 5), (Ed, Dirk Hansohm, W.B., Trudi Hartzenberg, Colin McCarthy).

[29]. United Nations Economic Commission for Africa (UNECA) (2010), Assessing Regional Integration in Africa IV: Enhancing IntraAfrican Trade, Addis Ababa, Ethiopia

[30]. UNECA (2004), Assessing Regional Integration in Africa I, Communications Development Incorporated, Washington D. C., USA

[31]. Venables (2003), Winners and Losers from Regional Integration Arrangements, The Economic Journal, Volume 113 (490) pp 747 761

[32]. Www.sadc.int (accessed 20/10/14)

[33]. www.unctadstat.org (accessed 08/09/14)

[34]. William et al, (1997), Regional Integration in Sub Saharan Africa: A review of Experiences and Issue, Regional Integration and Trade Liberalization in Sub Saharan Africa, vol. I: Frame work, Issues and Methodological Perspectives, AERC publication.

[35]. World Bank (2008), New Development Strategy focuses on Regional Integration in Sub Saharan Africa, available on http://go.worldbank.org/F64WSMWOL0 